\title{
A testnevelés helyzete, céljai a köznevelésben és a felsőoktatásban
}

\author{
The state and aims of physical education in public and higher education
}

\author{
Szerző: Lőkös Dániel $\square$ \\ Budapesti Gazdasági Egyetem
}

Beküldve: 2017. 03. 19.

doi: 10.24365/ef.v59i3.264

\begin{abstract}
Összefoglaló: A testnevelés tantárgy jelentősége a köznevelési intézményekben messze felülmúlja a többi tantárgyét a fiatalok egészség-magatartásának kialakítása és a testi-lelki egészségre gyakorolt hatása szempontjából. A cikkben ismertetésre kerül a testnevelés és az iskolai sport jelenlegi helyzete Magyarországon és nemzetközi viszonylatban, kiemelve a felsőoktatásban betöltött szerepét. Lényeges kérdés, hogy a felsőoktatás milyen módon járulhatna hozzá a kialakított egészség-magatartás megőrzéséhez, az egészséges szemlélet és életmód további fejlesztéséhez. Korábbi felmérések igazolják, hogy a mindennapos testnevelés pozitív hatást gyakorol a gyermekek, a fiatalok fizikai aktivitására. A felsőoktatásban követni kellene a köznevelésben kialakított pozitív egészségszemléletet. Fontos lenne, hogy a jövő értelmisége a felsőoktatási tanulmányai alatt megfelelő értékként ismerje meg és tárja fel a tudatos egészségmegőrző testmozgás fontosságát, annak további tényezőit, aspektusait.
\end{abstract}

Kulcsszavak: mindennapos testnevelés; fizikai aktivitás; sportolásra való készenlét; egyetemista; egészség-magatartás

Summary: In the development of the health behaviour of the youth, effects of physical education on mental and physical health are far above the importance of other subjects in the public education. This paper reviews the state of physical education and school sports in Hungary, and in international contexts, focusing on their role in higher education, examines the extent to which higher education can contribute to enhancing health awareness and to the further promotion of a healthy lifestyle.

Previous surveys confirm the positive effects of everyday physical education on children's and young adult's physical activity. Results clearly show that students developed a positive attitude to health issues in primary and secondary education and regard health as a value. It is very important to ensure that students in higher education can gain an even deeper understanding of the importance and the different factors and aspects of health promotion and how physical exercise can contribute to their mental and physical health.

Keywords: everyday physical education; physical activity; readiness to do physical exercise; students; health behaviour

\section{BEVEZETÉS}

Ahogy a Szent-Györgyi Alberttől vett idézetben megjelennek a sport erényei, úgy mindez a testnevelés oktatásával kapcsolatban is elmondható: „A sport elsősorban szellemi fogalom. Egy sportcsapat a társadalomnak kicsinyített képe, a mérkőzés az életért való nemes küzdelem szimbóluma. (...) A sport a játék alatt tanítja meg az embert rövid idő alatt a legfontosabb polgári erényekre: az összetartásra, az önfeláldozásra, az egyéni érdek teljes alárendelésére, a kitartásra, a tettrekészségre, a gyors elhatározásra, az önálló megitélésre, az abszolút tisztességre, és mindenekelött a 'fair play', 
a nemes küzdelem szabályaira." Kotschy Beáta egyértelműen, lényegre törően foglalja össze a testnevelés-oktatás célját: a személyiségfejlődésben tervezett változások elérése a motoros oktatási folyamat eredményeként, a korszerű testkulturális múvelődési anyag feldolgozása során. ${ }^{1} \mathrm{~A}$ köznevelési intézménytípusokban és a felsőoktatásban egyaránt ez a célja a testnevelésnek. Az általános cél az, hogy a testnevelés a testkultúra múveltségtartalmának közvetítésével járuljon hozzá a művelt ember formálásához. A testnevelés a köznevelési intézményekben a sok tantárgy közül csak az egyik. Jelentősége azonban az egészségmegőrzés és a személyiségfejlődés tekintetében, valamint a testben és lélekben harmonikus, munkabíró generáció felnövekedése szempontjából az iskolai tantárgyak fölé emeli. ${ }^{2}$

A testnevelés megismerésének első szintje az óvodai nevelésben és alsó tagozat első osztályaiban jelentkezik. Itt elvárásként megjelenik az általános mozgáskészségek fejlesztése, új mozgásformák kipróbálása. A mozgásműveltség további építésében fontos szerepe van a sokoldalú gyakorlási lehetőségeknek és a mozgásos játékokkal való mozgástapasztalatok szerzésének. Az itt szerzett gyakorlat megalapozza a mozgás- és a sportmúveltség fejlesztési lehetőségeit a későbbi tanulmányok során. ${ }^{3}$

A felső tagozati és a középfokú tanulmányok ideje alatt a testgyakorlatok és a sportágak technikai készletének fejlesztése formálja az általánosan múvelt embert. $^{3}$

A testnevelés oktatásának harmadik szintje a felsőfokú intézményekhez kötődik, ahol azzal is hozzájárulhatnak a múvelt emberek képzéséhez, hogy biztosítják a testhezálló edzési formák, sportágak gyakorlásának lehetőségét. A felsőoktatási intézmény feladata az oktatás, illetve a kínálatbővítés. $^{3}$

A 2016/2017. tanévben kezdték meg felsőoktatási tanulmányaikat azok a diákok, akik középiskolai tanulmányaik során mindennapos testnevelésben részesültek. Több felsőoktatási intézmény is kezdeményezte a kötelező testnevelés bevezetését a tanmenetbe, ezzel is előremozdítva az egészséges életmódot. Sajnálatos módon az infrastrukturális helyzet az egyetemeken és főiskolákon is fejlesztésre szorul.

\section{TESTNEVELÉSÓRÁK ÉS KÖVETELMÉNYEK A FEJLETT NYUGATI ORSZÁGOKBAN}

Az Amerikai Egyesült Államokban (USA) egyre nagyobb problémát jelent az elhízás és a testmozgás hiánya, amelyek már az általános iskolás korosztályban megmutatkoznak: bár államonként változnak a követelmények, gyakori, hogy az iskolákban csak hetente egyszer 40 perc kötelező testnevelés van a gyerekeknek. Ha valaki mozogni, sportolni akar, az órák utáni foglalkozásokhoz csatlakozhat. 2008-2011 között 300000 tanár vesztette el az állását az USA-ban, ami az 54\%-át jelentette az összes elvesztett állásnak a közszférában. Ennek következtében az osztálylétszámok nőttek, és a testnevelési (és múvészeti) órákat a többi, ebben képzetlen tanárnak kellett oktatnia, figyelmen kívül hagyva azt, hogy a testnevelésórák segíthetnének a kormánynak a költségek megtakarításában az egészségügyben, tekintve, hogy évi 147 milliárd dollárt költenek csak az elhízásból eredő betegségek kezelésére. ${ }^{4} \mathrm{Az}$ amerikai egyetemeken nincs kötelező testnevelésóra, az általános iskolákhoz hasonlóan órák utáni foglalkozásokon van lehetőségük a diákoknak mozogni.

Az USA-ban a 2-19 évesek között legmagasabb arányban, nemtől függetlenül a 12-19 éveseknél mutatható ki az elhízás, és alapvetően a 2-19 éves gyerekek 17\%-a számít elhízottnak. ${ }^{5}$

Az Egyesült Királyságban mind az általános, mind a középiskolákban az iskola vezetősége szabadon megszabhatja, hogy heti hány órában oktatnak testnevelést. Korábban heti két óra megtartása volt a jellemző, de bővítették a délutáni szabadon választható sportfoglalkozások kínálatát. ${ }^{6} \mathrm{Az}$ Egyesült Királyságban négy különböző stádiumra bontották a követelményeket, amelyeket az általános és középiskolákban kell teljesíteniük a diákoknak: az egyszerúbb feladatoktól haladnak a nehezebbek felé az évek során, és olyan sportok tartoznak ide, mint a futás, az úszás és a tánc. Középiskolában a csapatsportokra helyezik a hangsúlyt.7 A felsőoktatásban nincsenek kötelező testnevelésórák, csak szabadon választható délutáni csapatsportok: a legnépszerúbb a futball és a rögbi. ${ }^{6}$ 
AZ EURÓPAI UNIÓ, AZ UNESCO ÉS AZ EGÉSZSÉGÜGYI VILÁGSZERVEZET ÁLLÁSPONTJA

Az Európai Unió (EU) hivatalos iránymutatásai kifejezetten azokra az egészségügyi problémákra próbálják felhívni a figyelmet, amelyek a fizikai aktivitás csökkenése miatt (a fiatalabb korosztályokban) kialakultak. A felmérések szerint az iskoláskorú gyermekek $80 \%$-a kizárólag az iskolában végez testmozgást, miközben legalább napi 1 óra mozgásra lenne szükségük, amellyel hosszú távon támogatnák az egészségüket.

A 2009-es Lisszaboni szerződés 165. cikkelye ezekre a problémákra fókuszálva ad iránymutatást az EU országainak az iskolás korosztály megfelelő mennyiségú és minőségű testmozgására és sportfoglalkoztatására. A szerződés olyan pontokat foglal magában, mint a tagállamok és az iskolák közötti megfelelő kommunikáció, a távoktatás erősítése, a diákok és a tanárok mozgásra késztetése.

Több tagállam jelenleg is dolgozik új stratégiák kidolgozásán, a sport és a testnevelés népszerüsítésén. Szlovénia 2010-ben, Románia és Lettország pedig 2012-ben véglegesítette az új terveket. Romániában 2012 és 2020 között kerül sor a terv végrehajtására az állami iskolákban, az iskolai testnevelésre és a sportokra összpontosítva. ${ }^{8}$

Dániában 2012-ben kezdtek el új iránymutatásokon dolgozni, a fő cél a testnevelésórák fontosságának hirdetése, ami elősegíti a hatékony tanulást, erősíti a szociális és személyes készségeket és motiválja a diákokat. Lettországban 2013-2020 között vezetik be az új irányelveket, kiemelve a gyermek- és ifjúsági sportolás, a fogyatékossággal élő diákok testmozgása, infrastruktúra fejlesztése és pénzügyek területeit. 2013 óta Ausztria is új stratégián dolgozik, az egészséges életmód népszerűsítését helyezte a középpontba az iskoláskorú gyermekek között.

Jogilag a testnevelésóra ugyanolyan fontos a tagállamok 90\%-ában mint más órák, de a gyakorlatban 34\%-kal kevesebbet ér az emberek szemében. Kevesebbet és „lazábban” tanítják, mint a többi, kötelező és fontos tantárgyat, valamint a testnevelő tanárok megítélése is rosszabb a többiekhez képest (pl. matematika, kémia, nyelvi tárgyak). ${ }^{9}$

Az egészség és a testmozgás közötti összefüggés már régóta ismert. Az Egészségügyi Világszervezet (WHO) szerint a fizikai inaktivitás a halálozás negye- dik vezető kockázati tényezője a világon. A fejlettebb országokban ez még inkább jellemző, de kutatások kimutatták, hogy az állandó gazdasági fejlesztések és változások miatt most már a fejlődő országokban is egyre gyakoribb probléma a kevés testmozgás és az ehhez kapcsolódó egészségügyi kockázat. A WHO iránymutatása szerint minden 5-17 év közötti gyermeknek napi legalább 60 perc, minimum közepes intenzitású testmozgást kellene

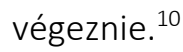

Az ENSZ Nevelésügyi, Tudományos és Kulturális Szervezete, az UNESCO is közzétette az álláspontját 2015-ben ${ }^{11}$ : megerősítette a 2013-as Berlini nyilatkozatot, amely kimondja, hogy a testnevelésóra a leghasznosabb módja a gyermekek és az ifjúság készségeinek fejlesztésére, motiválására és felkészítésére a társadalomban való elhelyezkedésre. A szervezet számos projektet vezet, támogat világszerte e nyilatkozat szellemiségében. ${ }^{12}$

\section{AZ ISKOLAI TESTNEVELÉS JELENLEGI HELYZETE MAGYARORSZÁGON}

Magyarországon a népességszám 37 éve folyamatosan csökken, öregszik a társadalom, sok a szívérrendszeri, daganatos és cukorbetegség, gyakori a csontritkulás, sűrün jelentkeznek a testtartáshibák, mozgásszervi panaszok és pszichés zavarok. A 15-16 éves fiatalok több káros szenvedélynek hódolnak (dohányzás, alkohol, drog). ${ }^{13} \mathrm{~A}$ helytelen táplálkozásból és a mozgásszegény életmódból fakadó elhízás hazánkban, de az EU tagállamaiban is komoly probléma. Magyarországon a 15 év alatti gyermekek $16 \%$-a túlsúlyos ${ }^{14}$, míg a 15 évesnél idősebb lakosság $2 / 3$ része túlsúlyos vagy elhízott. ${ }^{15}$ A magyar kormány a romló tendencia megállítására és egy egészségesebb társadalom megteremtésének céljából konkrét intézkedéseket tett a mindennapos testnevelés bevezetésével. A bevezetésről szóló jogszabály a nemzeti köznevelésről szóló CXC. törvényben (Nkt.) került előírásra. ${ }^{16}$ Az Nkt. 27. § (11) bekezdés szerinti mindennapos testnevelést az iskolai nevelés-oktatás első, ötödik, kilencedik évfolyamán 2012. szeptember 1-jétől kezdődően felmenő rendszerben kellett bevezetni, ami a 2015/2016. tanévben befejeződött. Az ezeken az évfolyamokon alkalmazott helyi tantervbe legalább heti öt testnevelési órát kellett beépíteni. Az új 
köznevelési törvény fókuszpontba helyezte a testnevelés és egyéb iskolai sportfoglalkozások szervezését. ${ }^{17}$

A Nemzeti alaptanterv (NAT) megújításakor a testnevelés egészségfejlesztési szempontjai hangsúlyosan jelentek meg. A mindennapi testnevelés megvalósulásának elmúlt éveiben kiderült, hogy egyre jobban előtérbe kerül a tornatermek hiánya: azokban az iskolákban, ahol korábban elegendő volt a meglévő tornaterem, most kevésnek bizonyulhat. Ez szükségessé teszi újabb tornatermek építését, ami szerepel is a kormányzati tervekben. Ezen túl a kormányzat uszodák építésével is segíteni kíván a mindennapi testnevelés infrastrukturális gondjain. Mindez jó és szükséges, azonban azt is látni kell: nem várható, hogy a közeljövőben minden tanuló, minden nap tornateremben vehessen részt a testnevelési óráján. ${ }^{18}$ Bár közel sem ideálisak az infrastrukturális feltételek sok helyen, a testkulturális múveltségterület iránt mélyen elkötelezett pedagógusok jó szervezéssel és áldozatos munkával színvonalasan megoldhatják a feladatokat. Ugyan a körülmények nagyon fontosak, az elhivatott tanárok személye, attitűdje még annál is többet jelent.

A mindennapi testnevelést akadályozó szabályozási, tárgyi és iskolai hozzáállásbeli problémákat rendszerszerúen kell kezelni. Az iskolák fokozott támogatása szükséges a mindennapi testnevelés kreatív, hatékony megoldásához, és ehhez a szülők, a tanulók és az iskolákat körülvevő civil társadalom bevonását is elő kell segíteni. ${ }^{18}$ Országos reprezentatív kutatási eredmények szerint a mindennapos testnevelés bevezetésével a megkérdezett felnőtt lakosság 70\%-a is egyetért. ${ }^{19}$

A testnevelés- és sportműveltségi terület régen túllépte hagyományos szemléletű tantárgyi kereteket, az egészség-magatartás állandó formálója lett. Részt vesz a mindennapos testedzés és testhasználat mellett a tartalmas életidő, az egészséges táplálkozás alakításában, hatással van a környezeti és a személyes higiéniára, a testi-lelki harmónia megteremtésére, szerepe van a testi eltérések korrekciójában, a rehabilitációban és a viselkedési devianciák, káros szenvedélyek elleni küzdelemben is. A nemzeti köznevelésről szóló törvény kimondja, hogy a köznevelés egészét a fenntartható fejlődés és az egészséges életmódra nevelés határozza meg. Megállapítható, hogy a mindennapos testnevelés bevezetésével a tantárgy jelentősége erősebbé vált, így a testnevelő tanár szerepe is felértékelődött.
Szabadon választott érettségi tantárgyként is egyre népszerúbb lett. A hatékony iskolai egészségfejlesztés a különböző múveltségi területek együttmúködésével érhető el, amelyet a testnevelő koordinál(hat). ${ }^{20}$ 2012-ben, a mindennapos testnevelés bevezetésével olyan utat kezdtek kiépíteni, ami elvezethet egy egészségesebb társadalom létrehozásához, de az infrastruktúra kiépítése hosszadalmas folyamat.

2014-ben jelent meg a felsőoktatással foglalkozó uniós fejlesztő projektek körében a Nemzeti Egészségfejlesztési Intézet és az Állami Egészségügyi Ellátó Központ konzorciuma által megvalósított, a TÁMOP 6.1.1./12/1. „Bizonyítékokon alapuló egészségfejlesztési ismeretek kidolgozása az oktatás különböző szintjei számára, valamint egészségfejlesztési szakmai hálózat létrehozása" című fejlesztő célú kiemelt projekt, amely a nagy társadalmi alrendszerekben folyó egészségfejlesztési munkák támogatását és koordinálását tǔzte zászlajára. A tényleges fejlesztési tevékenységek négy alprojekt - köznevelési, felsőoktatási, népegészségügyi és egészségfejlesztő kórházak alprojekt - keretében valósultak meg. Az egyetemek szempontjából releváns felsőoktatási alprojekt ahhoz kívánt hozzájárulni, hogy az egészség jelenjen meg hangsúlyosan a felsőoktatási intézmények mindennapjaiban, és az egyetemeken és fóiskolákon dolgozók egészségtudatos gondolkodására és viselkedésére kíván hatni. A TÁMOP-6.1.1-12/1 program felsőoktatási alprojektjének újszerúségét az is adta, hogy ez volt az első átfogó, országos kezdeményezés az egészségfejlesztő egyetem külföldön már ismert és múködő koncepciójának, módszertanának hazai adaptációjára és bevezetésére, és az egészségfejlesztő egyetemek hálózatának kialakítására. ${ }^{21}$

\section{A FELSŐOKTATÁSI TESTNEVELÉS ÉS AZ EGYETEMI SPORT HELYZETE, CÉLAI MAGYARORSZÁGON}

A felsőoktatási intézményeken a testnevelés és a sport nem központilag kiadott tantervek alapján szerveződik. Az egyetemekre, főiskolákra érkező hallgatók már részesültek köznevelésben. Ha minden intézményben és életkorban megfelelő hatásfokú testnevelési oktatást kaptak, már rendelkeznek általános testkulturális múveltséggel, így a felsőoktatási intézmények feladata a testnevelés- 
oktatásban az, hogy biztosítsa az eddig megalapozott képességek egészségtudatos szemléletû további fejlődését, valamint az ehhez szükséges megfelelő körülményeket. Az infrastrukturális ellátási nehézségek ellenére több felsőoktatási intézmény bevezette kötelező tantárgyként a testnevelést.

A sport, a mozgás és az ennek következtében kialakuló mozgásgazdag életmód, egészségtudatos magatartás olyan igény az ember számára, amelyet élete során sajátít el. ${ }^{22}$

A Magyar Egyetemi - Főiskolai Sportszövetség (MEFS) által koordinált, katalizált versenyrendszerrel kibővül az adott intézmény nyújtotta sportolási lehetőség. Cél, hogy az egyetemek és főiskolák ne csak a saját tudományterületükön speciális szaktudással rendelkező szakembereket neveljenek, hanem mozgásban gazdagabb életet élő, egészségtudatos fiatalokat, akik munkavállaló korukban a fitt életszemlélet és az egészségtudatos magatartás elkötelezettjeiként a társadalom hasznosabb tagjai, a gazdaság hatékonyabb szereplői lehetnek.

A jövő generációjának felelősségteljes, egészségtudatos életre nevelése alapvető társadalmi feladat. ${ }^{23}$ A Magyar Egyetemi - Főiskolai Sportszövetség 2013-ban elkészítette a Hajós Alfréd-tervet, amely a felsőoktatási sport területére vonatkozó szakmai programterv 2020-ig. A Hajós Alfréd-terv célja az önkéntes mindennapos testedzés megvalósítása a hazai felsőoktatásban, valamint az évszázados hagyományokon alapuló egyetemi sport presztízsének és beágyazottságának növelése. ${ }^{24}$

Az aktívan sportolók aránya jelenleg nagyon alacsony, és ez az egyetemi-főiskolai korosztályban is csak alig érezhetően magasabb. ${ }^{24}$

A hallgatók döntő többsége nem sportol rendszeresen, ezért fontos lenne a testnevelésórák számának és minőségének növelése, javítása, hogy a fizikailag inaktív fiatal felnőttek találkozzanak a testkulturális értékekkel. Emiatt is kiemelten fontos lenne a felsőoktatásban a központilag előírt testnevelés, és az oktatás tartalmának meghatározása, a tárgyi és személyi feltételek biztosítása.

A Hajós Alfréd-terv kiemelt feladatként fogalmazza meg a jelenleg még nem sportoló hallgatói tömegek elérését és megmozgatását. A magyar felsőoktatás egészséges és sportos életmódot középpontba állító átalakítása csak akkor képzelhető el, ha a változó környezettôl és befolyásoló erőktől független, de mindenki által elfogadható célokat tǔz ki. A tervbe tartoznak sportösztöndíjak és mentorprogramok is. ${ }^{24}$

Magyarországon a rendszeres és rekreációs minimumot elérő testmozgást végzők, valamint az aktívan sportolók aránya alacsony, és ez az arány sajnos alig magasabb a felsőoktatásban tanuló korosztályban. A pozitív változást jelentő folyamatoknak köszönhetően 2013-tól a tendencia javul. ${ }^{24}$

A Magyar Egyetemi - Főiskolai Sportszövetség először a 17. Educatio kiállításon, 2016-ban vizsgálta leendő egyetemisták sportolási szokásait kérdőíves felméréssel. A kérdőív kitöltése önkéntes alapon történt a MEFS munkatársainak felkérésére, illetve közremúködésével. Ehhez mérten az eredmények nem reprezentatívak, és az ezekből levont következtetések is korlátozott érvényűek. A 2016-ban végzett felmérés eredménye szerint a versenysport területén a köznevelésből kikerülő élsportolók választási kényszerként tekintenek arra, hogy sportoljanak vagy tanuljanak: a felsőoktatás első éveiben a legnagyobb az élsportolók lemorzsolódása. A kötelező testnevelésórákon kívül az alábbi arányokban sportoltak a hallgatók a végzett felmérés alapján. [1. táblázat] $]^{24}$

1. táblázat: A Magyar Egyetemi - Föiskolai Sportszövetség 2016-os felmérése alapján a kötelező testnevelésórákon kívül sportoló hallgatók aránya ${ }^{24}$

\begin{tabular}{|c|c|c|}
\hline A testmozgás gyakorisága & $\begin{array}{c}\text { Közoktatásban } \\
\text { fő (százalék) N=16502 }\end{array}$ & $\begin{array}{c}\text { Egyetemen } \\
\text { fő (százalék) N=16503 }\end{array}$ \\
\hline ritkábban, mint havonta & $1707(10,3 \%)$ & $2331(14,1 \%)$ \\
\hline havonta & $2055(12,4 \%)$ & $2746(16,6 \%)$ \\
\hline heti rendszerességgel & $4582(27,8 \%)$ & $5097(30,9 \%)$ \\
\hline hetente 2-3 alkalommal & $4651(28,2 \%)$ & $3976(24,1 \%)$ \\
\hline legalább heti 4 alkalommal & $3507(21,2 \%)$ & $2353(14,3 \%)$ \\
\hline
\end{tabular}

Forrás: MEFS-adatok alapján saját szerkesztés 
Az MEFS kérdőíve szerint a testmozgást végzők aránya igen magas a felsőoktatásba készülő, a közoktatásban négy éven át mindennapos testnevelésben részesült, leendő hallgatók körében. A fiatalok pozitív hozzáállását tükrözi, hogy többségük szívesen próbálná ki magát több különböző sportágban is. A mozgásformákat tekintve a tradicionális mozgásformák preferáltak: a nők legmagasabb arányban az aerobikot, a férfiak a futballt, kézilabdát és a kosárlabdát szeretik ǔzni, ami megegyezik a mai trendekkel.

A Magyar Egyetemi - Főiskolai Sportszövetség iránt a jelenleg is fizikailag aktív diákok érdeklődnek. Az eredmények szerint a sportolók az egyetemi tanulmányi éveik alatt sem szeretnének változtatni sportolási szokásaikon, és az erre fordított időmenynyiségen sem. A megkérdezettek igen magas arányban gondolják, hogy az egyetemi élet szerves részét kellene hogy képezze az egyetemi sportélet is, ami egyúttal szerepet játszik az egyetem kiválasztásának szempontjai között is. Ez a pozitív hozzáállás egyben elvárást is tükröz.

A testnevelés tantárgy szerepe és megítélése egyre erősebb és jobb a köznevelésben, és ez a tendencia a későbbiekben valószínúleg a felsőoktatási intézményekben is megmutatkozik. A mindennapos testnevelés bevezetése hatékonyan ösztönzi a diákokat a testmozgásra, ami a jövőben egy egészségesebb társadalom felépüléséhez vezethet. A korai halálozáshoz, valamint a munkaképesség csökkenéséhez vezető civilizációs népbetegségek megelőzhetők, és ennek a megelőzésnek az egyik fontos eszköze a gyermekkorban elkezdett rendszeres testmozgás. ${ }^{25}$

\section{ÖSSZEGZÉS ÉS JAVASLAT}

„A sport nemcsak testnevelés, hanem a léleknek is az egyik legerőteljesebb nevelőeszköze" (SzentGyörgyi Albert).

A mindennapos testnevelés bevezetése a köznevelésben pozitív hatást okozott. Szükségszerű, hogy a felsőoktatás is rendelkezzen ezekkel az értékekkel. Komoly veszély, ha a felsőoktatás nem épít a köznevelésben jól múködő mindennapos testnevelésre: a fiatal felnőttekben a kellő tudatosságot, az egészségtudatos fizikailag aktív életvitel gyakorlásá- nak igényét ezekben az években lehet és kell megalapozni. Amennyiben nem fordítunk kellő figyelmet a köznevelésben kialakított igények egyetemi rendszerbe való adaptálására, elmulasztjuk az egyetemista korosztályban a testkulturális értékek tudatosítását, ami miatt jelentősen csökkenhet a későbbi felnőtt munkavállalók addig megszerzett törekvése, motiváltsága az egészséges életmódra, a fizikai aktivitásra.

Az értelmiség mintaadó szerepet játszik a társadalom életében, ezért kiemelten fontos, hogy a hallgatók, a jövő értelmisége felsőoktatási tanulmányai alatt megfelelő értékként ismerje meg a tudatos egészségmegőrző testmozgást, melynek kiváló eszköze lehet a testnevelés tantárgy elméleti ismereteinek oktatása. Mindezt ki kell egészíteni olyan, a hallgatók számára testi-lelki örömszerzést biztosító, hatékony egészségmegőrző gyakorlati órákkal, amelyeket a legmagasabb szinten képzett, lelkiismeretes szakemberek tartanak. Emellett fontos, hogy kialakítsuk a közösségépítő, az adott felsőoktatási intézmény identitását erősítő, megfelelő egészségmagatartást és fittséget megalapozó szabadidő- és versenysport szervezeti formáját. A testnevelés-oktatást kiegészítve létesülhetne egyetemi sportegyesület, amellyel az egyetemi kereteken belüli versenyeztetést lehetne kiemelten támogatni, illetve egyéb szabadidős sportszolgáltatásokat nyújtani mind az egyetem oktatóinak, dolgozóinak, mind a hallgatóknak. A sportegyesület mindenképpen színesítené az egyetemi életet nemcsak a sport terén, hanem az ezzel egybekötött kulturált szórakozási színtéren is, a marketing- és közösségépítő hatás is jelentős lenne mind magyarországi, mind nemzetközi szinten. A megalakuló egyetemi sportegyesület a tagsági díjakon felül, az egyetem támogatásával, szponzorokkal és a MEFSpályázatokon való sikeres részvétellel tudna anyagi támogatáshoz jutni.

Alapvető társadalmi feladatnak kell tekinteni a hallgatók felelősségteljes és egészségtudatos életre nevelését. A felsőoktatásban a nem testkulturális területek vezetői körében is komoly szemléletváltásra lenne szükség ahhoz, hogy érvényesüljön a testnevelés és a sport múveltségterületének egyenértékűsége más területekkel, illetve az egészségmegőrzésben betöltött szerepének kiemelt fontossága. 
HIVATKOZÁSOK

${ }^{1}$ Kotschy B. Az oktatás célrendszere. In: Falus I (ed.). Didaktika. Elméleti alapok a tanítás tanulásához. Nemzeti Tankönyvkiadó, Budapest, 2003. pp 108.

${ }^{2}$ Varga Z. Az iskolai testnevelés helyzete és az ifjúság egészségügyi állapota. Vas Megyei Közgyúlés, Szombathely, www.vasmegye.hu/upload/ules/iskolai-testneveles.doc, 2009.03.06. pp 2, 30.

${ }^{3}$ Rétsági E. A testnevelés oktatás elméleti alapjai. In: Nádori L, Gáspár M, Rétsági E, et al. (eds.). Sportelméleti ismeretek. Dialóg Campus Kiadó, Budapest, 2011. pp 18-20.

${ }^{4}$ Spark. The Effect of Budget Cuts on Physical Education. http://www.sparkpe.org/blog/the-effect-of-budget-cuts-onphysical-education/, 30 January 2012. Elérve: 2017. 10. 02.

${ }^{5}$ Ogden CL, Carroll MD, Fryar CD, et al. Prevalence of Obesity Among Adults and Youth: United States, 2011-2014. NCHS Data Brief, No. 219., November 2015.

${ }^{6}$ Ofsted Annual report. Beyond 2012 - outstanding physical education for all. https://www.gov.uk/government/uploads/system/uploads/attachment data/file/413187/Beyond 2012 - outstanding physical education for all.pdf, 2012. Elérve: 2017. 12. 01.

${ }^{7}$ GOV.UK. National Curriculum in England: PE programmes of study. Department for Education, https://www.gov.uk/government/publications/national-curriculum-in-england-physical-education-programmes-ofstudy, 11 September 2013. Elérve: 2017. 12. 01.

${ }^{8}$ European Commission (EACEA) Eurydice, 2013. Eurydice report. Physical Education and Sport at School in Europe. Luxembourg: Publications Office of the European Union, 2013. http://eacea.ec.europa.eu/education/eurydice/documents/thematic reports/150EN.pdf, 2013. doi:10.2797/49648 Elérve: 2017. 12. 01.

${ }^{9}$ Hardman K. Human Movement- The situation of physical education in school: A European perspective. University of Wocester, United Kingdom, 2008. doi: 10.2478/v10038-008-0001-z

${ }^{10}$ World Health Organisation: Global Strategy on Diet, Physical Activity and Health. http://www.who.int/dietphysicalactivity/factsheet young people/en/, 2017. Elérve: 2017. 10. 02.

${ }^{11}$ United Nations Educational, Scientific and Cultural Organization (UNESCO). International charter of physical education, physical activity, and sports. http://unesdoc.unesco.org/images/0023/002354/235409e.pdf, 2015. Elérve: 2017. 10. 02 .

12 United Nations Educational, Scientific and Cultural Organization. Declaration of Berlin. http://unesdoc.unesco.org/images/0022/002211/221114e.pdf, 2013. Elérve: 2017. 10. 02.

${ }^{13}$ European School Survey Project on Alcohol and Other Drugs. Espad report 2015. http://www.espad.org/country/hungary, 2015. Elérve: 2017. 10. 02.

${ }^{14}$ Organisítion for Economic Co-operation and Development. Obesity Update 2017. http://www.oecd.org/health/health-systems/Obesity-Update-2017.pdf, 2017. Elérve: 2018. 04. 20.

${ }^{15}$ Erdei G, Kovács VA, Bakacs M, et al. Országos Táplálkozás és Tápláltsági Állapot Vizsgálat 2014. I. A magyar felnőtt lakosság tápláltsági állapota. Orvosi Hetilap. 2017;158(14):533-540. doi: 10.1556/650.2017.30700

${ }^{16}$ Nemzeti köznevelésről szóló 2011. évi. CXC. törvény

${ }_{17}$ Magyarországi Szülők Országos Egyesületének szakképzési honlapja. A mindennapos testnevelés 2017. http://www.mszoe.hu/index.php?oldal=alap.php\&id=121, 2017. Elérve: 2017. 12. 01.

${ }^{18}$ Somhegyi A. A mindennapi testnevelés egészségfejlesztési kritériumai: megvalósításuk jelen helyzete. Népegészségügy. 2014;92(1):4-10.

${ }^{19}$ Borbély Sz. As parents see physical education (PE) from a representative survey's point of view. In: Karlovitz JT (ed.). Mozgás, környezet, egészség. International Research Institute, 2014. pp 39-54.

${ }^{20}$ Bollók S, Takács J. Testnevelés - „a vezető tárgy". XII. Országos Sporttudományi Kongresszus, Magyar Sporttudományi Szemle. 2015/2;16(62):24.

${ }^{21}$ Kraiciné Sz. M. Egészségfejlesztés a felsőoktatásban - Gondolatok egy felsőoktatást érintő projekt zárása kapcsán. Opus et Educatio. 2016;10(3):5.

22 Berkes P. A testnevelés tantárgy értékelési dilemmái. Új Pedagógia Szemle. 2005;2:63-68.

${ }^{23}$ Ádány R. A magyar lakosság egészségi állapota, különös tekintettel az ezredforduló utáni időszakra. Népegészségügy. 2008;86(2):5-20.

${ }^{24}$ Magyar Egyetemi - Főiskolai Sportszövetség. Hajós Alfréd Terv. https://mozduljra.hu/tartalmak/hajos alfred terv 2013 2020, 2013. január 31. Elérve: 2017. 12. 01.

${ }_{25}$ Pavlik G. A rendszeres fizikai aktivitás szerepe a betegségek megelőzésében, az egészség megőrzésében. Egészségtudomány. 2015;59(2):11-26. 